Acta Zoológica Mexicana (nueva serie), Volume 38, 1-11.

https://doi.org/10.21829/azm.2022.3812443

http://zoobank.org/urn:Isid:zoobank.org:pub:28986674-375C-4D29-A02A-B2233FE0A208

Original paper

\title{
A new species of the genus Cryptocanthon from Peru (Coleoptera: Scarabaeidae: Scarabaeinae)
}

\section{Nueva especie del género Cryptocanthon de Perú (Coleoptera: Scarabaeidae: Scarabaeinae)}

\author{
AlFREDO EdgARDO GIRALDO-MENDOZA \\ Universidad Nacional Agraria La Molina - Museo de Entomología Klaus \\ Raven Büller. Av. La Molina s/n, Lima 12, Lima, Perú.
}

Responsible editor: Magdalena Cruz Rosales

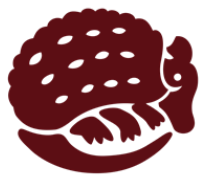

OPEN ACCESS

*Corresponding author:

Alfredo Edgardo Giraldo-Mendoza aegmendoza@gmail.com

Cite:

Giraldo-Mendoza, A. E. (2022) A new species of the genus Cryptocanthon from Peru (Coleoptera: Scarabaeidae: Scarabaeinae). Acta Zoológica Mexicana (nueva serie), 38, 1-11.

10.21829/azm.2022.3812443 elocation-id: e3812443

Received: 20 August 2021 Accepted: 28 January 2022 Published: 10 February 2022
ABSTRACT. A new brachypterous species of Scarabaeinae, Cryptocanthon iskaypachak sp. nov. is described, discussed and illustrated based on specimens collected in Cajamarca department. The new species is the third of the genus Cryptocanthon recorded from Peru.

Key words: Demarziellini; dung beetles; Neotropics; South America; Systematics

RESUMEN. Se describe, discute e ilustra una nueva especie braquíptera de Scarabaeinae, Cryptocanthon iskaypachak sp. nov. con base en especímenes recolectados en el departamento de Cajamarca. La nueva especie es la tercera registrada para el género Cryptocanthon en Perú.

Palabras clave: Demarziellini; escarabajos coprófagos; Neotrópico; Sudamérica; Sistemática

\section{INTRODUCTION}

The genus Cryptocanthon was described by Balthasar (1942) to place the dung beetle species Cryptocanthon paradoxus Balthasar, 1942 based on a single male specimen from Loja province (Villonaco) in southern Ecuador. During the eight subsequent decades, 41 species were added to the genus, eight 
species from Brazil, Colombia, Mexico and Venezuela (Howden, 1973), two species from Colombia and Mexico (Howden, 1976), two species from Costa Rica and Panama (Howden \& Gill, 1987), 22 species from Colombia, Costa Rica, Ecuador, French Guiana, Mexico, Panama and Venezuela (Cook, 2002), three species from Colombia (Arias \& Medina, 2014), one species from Mexico (MoraAguilar \& Delgado, 2018) and three species from Colombia (Martinez-Revelo et al., 2020). A complete list of Cryptocanthon species is presented in Table 1.

The systematic position of Cryptocanthon is still doubtful, although traditionally it has been placed in the tribe Deltochilini (= Canthonini), it should be included in the tribe Demarziellini according to available morphological evidence (Vaz-de Mello, 2007; Martínez-Revelo et al., 2020). While the highest species richness for this genus is in Colombia with 15 species (Martínez-Revelo et al., 2020), Mexico with ten species (Mora-Aguilar \& Delgado, 2018) and Ecuador with six species (Chamorro et al., 2019), only two species have been recorded from Peru (Ratcliffe et al., 2015). The two species previously recorded from Peru are the following ones: Cryptocanthon campbellorum Howden, 1973, known from Brasilia and Pará in Brazil, Caquetá, Meta and Vaupes in Colombia and Madre de Dios in Peru (Cook, 2002; Arias \& Medina, 2014; Martinez-Revelo et al., 2020), and C. paradoxus, known from Ecuador (Loja, Villonaco) and Peru (Piura, Ayabaca) (Chamorro et al., 2019; Juárez-Noe \& Gonzalez-Coronado, 2021).

The objective of this paper is to describe a new species of Cryptocanthon from Cerro Coymolache, Hualgayoc, in northern Peru (Cajamarca).

\section{MATERIALS AND METHODS}

The author reviewed Scarabaeinae specimens housed at Museo de Entomología Klaus Raven Büller (MERKB), during which specimens attributed to a new species of the genus Cryptocanthon were found. Morphological terms were applied to make a consensus between basic terminology for Scarabaeinae genera (Vaz de Mello et al., 2011), with the most comprehensive review of the genus (Cook, 2002) and most recent species descriptions (Martinez-Revelo et al., 2020). The phylogenetic species concept (Wheeler \& Platnick, 2000) is followed in this work, which defines a species as the smallest aggregation of populations diagnosable by a unique combination of character states.

Type specimens of the new species were deposited in Museo de Entomología Klaus Raven Büller (MEKRB) and Museo de Historia Natural Javier Prado (MUSM). Label data for the new species is quoted verbatim; different lines of the label are separated by a diagonal slash (/), and different labels are indicated by square brackets ([ ]).

When it was necessary, specimens were dissected for better examination. Parameres were extracted, treated for 10 minutes in $20 \% \mathrm{KOH}$, washed with distilled water and adhered to a small piece of cardboard. The first approach to male specimens took into account the extraction of endophallites (Génier, 2019), since these sclerites have proved to be distinctive between Cryptocanthon species (Arias \& Medina, 2014; Martinez-Revelo et al., 2020). However, the detailed dissections that are required were not performed, due to a combination of lack of skills and fine 
instruments, both essential for the proper extraction and manipulation of structures measuring less than $0.5 \mathrm{~mm}$; these techniques were detailed by Medina et al. (2013).

Specimens were photographed with a Canon EOS Rebel T5i DSLR, equipped with Macro lens and rail. Each image includes a series of photos taken in different planes, which were stacked with the Combine ZP software (Hadley, 2006). Drawings were done by the prints of photographs, observations with a stereomicroscope and digital improving with graphic design software. Distribution map was prepared using SimpleMappr (Shorthouse, 2010).

Table 1. List of known species of genus Cryptocanthon, sorted according to their description date.

\begin{tabular}{|c|c|c|c|}
\hline & Species & Type locality & Country records \\
\hline 1 & C. paradoxus Balthasar, 1942 & Loja (Ecuador) & Ecuador, Peru \\
\hline 2 & C. lobatus Howden, 1973 & Veracruz (Mexico) & Mexico \\
\hline 3 & C. brevisetosus Howden, 1973 & Chiapas (Mexico) & $\begin{array}{l}\text { Mexico, } \\
\text { Guatemala }\end{array}$ \\
\hline 4 & C. cristobalensis Howden, 1973 & Chiapas (Mexico) & Mexico \\
\hline 5 & C. parvus Howden, 1973 & Valle (Colombia) & Colombia \\
\hline 6 & C. campbellorum Howden, 1973 & Brasilia (Brazil) & $\begin{array}{l}\text { Brazil, Colombia, } \\
\text { Peru }\end{array}$ \\
\hline 7 & C. nebulinus Howden, 1973 & Aragua (Venezuela) & Venezuela \\
\hline 8 & C. humidus Howden, 1973 & Valle (Colombia) & Colombia, Panama \\
\hline 9 & C. peckorum Howden, 1973 & Amazonas (Colombia) & Colombia, Brazil \\
\hline 10 & C. altus Howden, 1976 & Santander (Colombia) & Colombia \\
\hline 11 & C. newtoni Howden, 1976 & Chiapas (Mexico) & Mexico \\
\hline 12 & C. chiriquinus Howden \& Gill, 1987 & Chiriqui (Panama) & Panama \\
\hline 13 & C. lindemanae Howden \& Gill, 1987 & Puntarenas (Costa Rica) & Costa Rica \\
\hline 14 & C. andersoni Cook, 2002 & Merida (Venezuela) & Venezuela \\
\hline 15 & C. gilli Cook, 2002 & Bolivar (Venezuela) & Venezuela \\
\hline 16 & C. galbao Cook, 2002 & Saül (French Guiana) & French Guiana \\
\hline 17 & C. pumilus Cook, 2002 & Vaupes (Colombia) & Colombia \\
\hline 18 & C. bochilae Cook, 2002 & Chiapas (Mexico) & Mexico \\
\hline 19 & C. denticulum Cook, 2002 & Chiriqui (Panama) & Panama \\
\hline 20 & C. howdeni Cook, 2002 & Chiapas (Mexico) & Mexico \\
\hline 21 & C. montebello Cook, 2002 & Chiapas (Mexico) & Mexico \\
\hline 22 & C. ocosingo Cook, 2002 & Chiapas (Mexico) & Mexico \\
\hline 23 & C. osaensis Cook, 2002 & Puntarenas (Costa Rica) & Costa Rica \\
\hline 24 & C. rayonensis Cook, 2002 & Chiapas (Mexico) & Mexico \\
\hline 25 & C. solisi Cook, 2002 & Heredia (Costa Rica) & Costa Rica \\
\hline 26 & C. curticrinis Cook, 2002 & Napo (Ecuador) & Ecuador \\
\hline 27 & C. escobari Cook, 2002 & Boyacá (Colombia) & Colombia \\
\hline 28 & C. foveatus Cook, 2002 & $\begin{array}{l}\text { Cundinamarca } \\
\text { (Colombia) }\end{array}$ & Colombia \\
\hline 29 & C. genieri Cook, 2002 & Napo (Ecuador) & Ecuador \\
\hline
\end{tabular}




\begin{tabular}{llll}
\hline Species & Type locality & Country records \\
\hline 30 & C. lobipygus Cook, 2002 & Darien (Panama) & Panama \\
31 & C. medinae Cook, 2002 & Valle (Colombia) & Colombia \\
32 & C. napoensis Cook, 2002 & Napo (Ecuador) & Ecuador \\
33 & C. otonga Cook, 2002 & Cotopaxi (Ecuador) & Ecuador \\
34 & C. punctatus Cook, 2002 & Trujillo (Venezuela) & Venezuela \\
35 & C. urguensis Cook, 2002 & Napo (Ecuador) & Ecuador \\
36 & C. andradei Arias \& Medina, 2014 & Risaralda (Colombia) & Colombia \\
37 & C. buriticaorum Arias \& Medina, 2014 & Boyacá (Colombia) & Colombia \\
38 & C. pulidoae Arias \& Medina, 2014 & Risaralda (Colombia) & Colombia \\
39 & C. chimalapensis Mora-Aguilar \& & Oaxaca (Mexico) & Mexico \\
& Delgado, 2018 & & \\
40 & C. cephalopunctatus Martínez-Revelo, & Santander (Colombia) & Colombia \\
& $\begin{array}{l}\text { Torres \& Neita, 2020 } \\
41\end{array}$ C. encenillensis Martínez-Revelo, Torres & Cundinamarca & Colombia \\
& \& Neita, 2020 & (Colombia) & \\
42 & C. mailinae Martínez-Revelo, Torres \& & Antioquia (Colombia) & Colombia \\
& Neita, 2020 & & \\
43 & C. iskaypachak sp. nov. & Cajamarca (Peru) & Peru \\
\hline
\end{tabular}

\section{RESULTS AND DISCUSSION}

\section{Cryptocanthon iskaypachak Giraldo, new species (Figs. 1-3)}

http://zoobank.org/urn:Isid:zoobank.org:act:16176B7A-3E3B-457B-B1D4-747A6E6E49AF

Type locality: Cerro Coymolache ( $06^{\circ} 46^{\prime} 45.52^{\prime \prime}$ S, $78^{\circ} 36^{\prime} 57.97^{\prime \prime}$ W), Provincia de Hualgayoc, Cajamarca, Peru.

Deposit of types: Museo de Entomología Klaus Raven Büller, Universidad Nacional Agraria La Molina, Lima, Peru (MERKB) and Museo de Historia Natural Javier Prado, Universidad Nacional Mayor de San Marcos, Lima, Peru (MUSM).

Type material. Holotype (male): [PERU, Cajamarca, Hualgayoc/ Hualgayoc, Cerro Coymolache/06 ${ }^{\circ}$ 46' 45.52" S, 78 36' 57.97"' W/XI-2014, R. Sánchez coll.] [Puna grassland, 3,500 m, pitfall traps], with red holotype label (MEKRB). Paratypes (five males and eight females) with the same label data, with yellow paratype labels, four males and six females (MEKRB), one male and two females (MUSM).

Diagnosis. The following combination of characters characterizes this species: vertical surface of clypeus not foveate; posterior pronotal angles obtuse and weakly incised, pronotal hypomeron not carinate, pseudepipleuron lacking basal fovea; metathoracic wings greatly reduced, mesometasternal suture straight; male protibiae weakly notched, male metatibiae with internal margin crenulated; apical abdominal sternite not lobed posteriorly; pygidium without median depression at base and parameres with apices distally widened and domed, not setose. 
Description. Holotype. Male (Fig. 1A) (pinned and dissected). Total length: $5.2 \mathrm{~mm}$; humeral width: $3.1 \mathrm{~mm}$. Body shiny, dark brown, reddish on anterior margins of clypeus and pronotum, and on apices of femora and tibiae; covered with yellowish arched setae on pronotal and elytral margins, more conspicuous on posterior fourth of pronotum and posterior third of elytra.

Head (Fig. 2A). Clypeus not strongly produced anteriorly. Clypeal teeth moderately developed, widely separated, weakly reflexed. Clypeal emargination between teeth evenly rounded; vertical surface moderately broad, not foveate. Apical margin of clypeus lateral to teeth convexly sinuated. Disc of clypeus concave, with coarse punctures separated by a distance less than its diameter, punctures finer and sparser towards the anterior margin. Clypeogenal suture vaguely carinate. Gena slightly produced, forming a slight incision at junction with anterior margin of clypeus; coarsely, densely punctate such as the clypeus. Vertex with punctures similar to the clypeus and gena, without posteromedial depression.

Pronotum (Fig. 2B). Convex medially, laterally explanate, without shallow lateral depressions on posterior half. Anterior angles approximately right-angled. Lateral margin nearly straight both anterior and posterior to lateral angles. Posterior angles obtuse, each one preceded by a weak incision. Disc of pronotum with fine punctures separated by a distance equal to their diameter, punctures coarser and denser towards lateral margins. Pronotal hypomeron convex, with coarse and dense punctures, with evident microsculpture between punctures; not carinate posteriorly.

Elytra (Fig. 2C). Transversely and longitudinally strongly convex; lateral carinae not strongly elevated, without obvious setae on edge. Each elytron dorsally with seven striae, each stria indicated by two wavy lines. Elytral intervals slightly convex; with rows of punctures adjacent to striae. Pseudepipleuron broad, rather abruptly narrowed apically, lacking basal fovea, with impressed microsculpture; with scattered, minute punctures and erratic transverse wrinkles; striae 8 and 9 incomplete, faintly indicated by obscure wavy lines near middle; stria 10 incomplete, indicated by a row of punctures adjacent to epipleuron near middle. Epipleuron with erratically spaced, coarse punctures.

Wings. Metathoracic wings completely reduced. Venter (Fig. 2D). Prosternum surface with coarse punctures on lateral edge next similar to hypomeron. Mesosternum surface without evident microsculpture, with coarse punctures separated by less than their diameter. Meso-metasternal suture straight. Mesepisternum with similar surface than lateral margins of mesosternum. Metasternum surface without evident microsculpture, with coarse punctures separated by less than their diameter. Metepisternum with similar surface than lateral margins of metasternum.

Legs (Fig. 2E, G). Profemur with coarse and dense punctures on ventral surface. Protibia expanded medially in apical half, with three apical teeth on external margin, two distal teeth closest to each other and distant from proximal tooth, with smaller teeth between them; with a weakly pre-apical notch on inner margin. Protibial ventral surface smooth, with well-marked central carina, glabrous. Mesofemur and metafemur with coarse and dense punctuation on ventral surface. Mesotibia apically dilated, with two lateral rows of yellowish setae on lateral margins, from middle 
to apex. Metatibia strongly curved; dorsal surface flattened with two rows of setae from middle to apex; internal lateral margin slightly crenulated from middle to apex, external lateral margin apically carinated.

Abdomen (Fig. 2l). Apical sternite with coarse and dense punctures, not lobed posteriorly. Pygidium convex, glabrous, with coarse punctures, without median depression at the base. Male genitalia (Fig. 2J, K). In lateral view, parameres with dome-shaped apices, distally directed downwards. In caudal view, parameres are wider basally, narrowed at middle and widened towards apices; apices are distally domed, not setose.
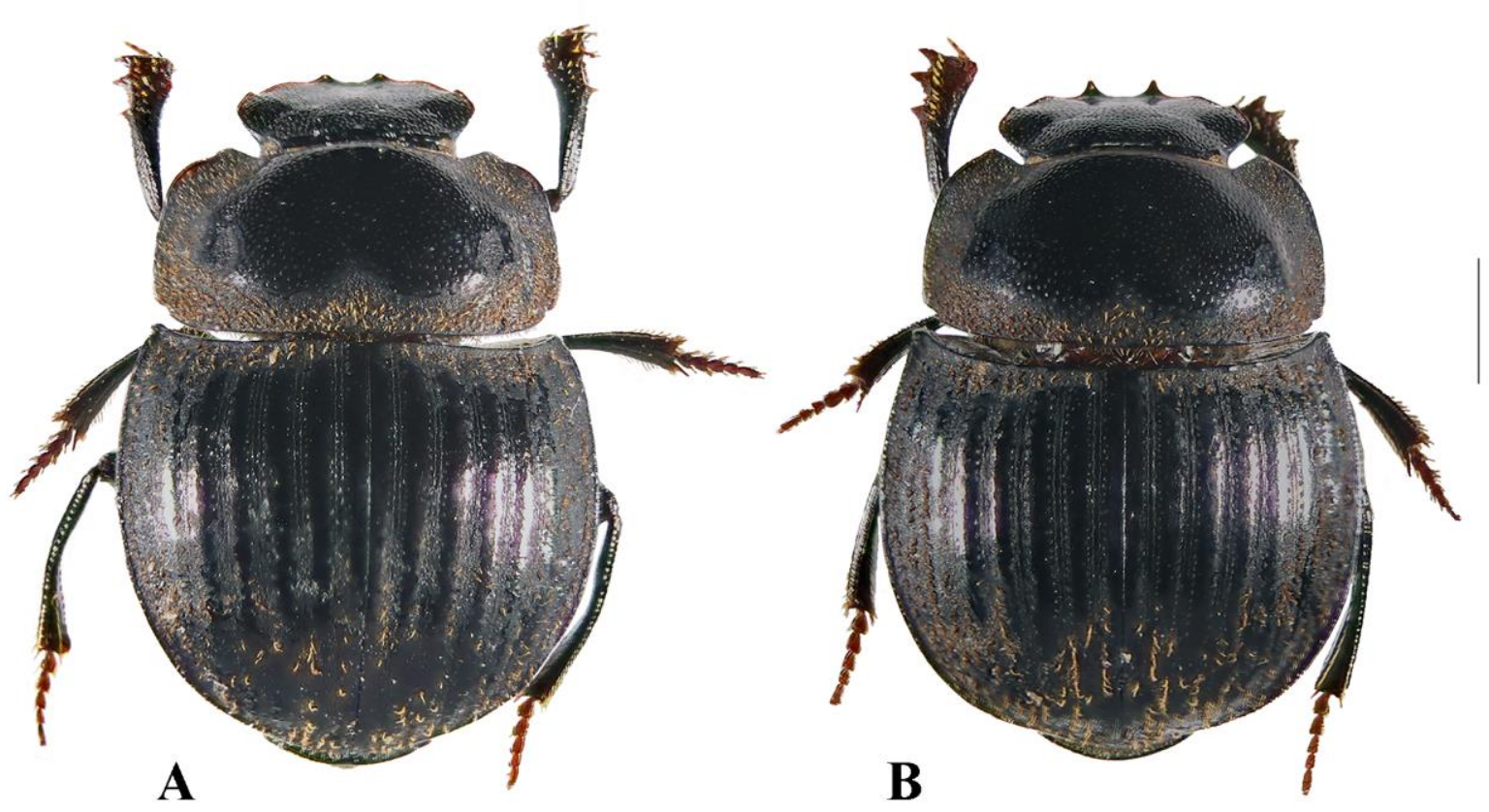

Figure 1. Cryptocanthon iskaypachak sp. nov. habitus: A) Male holotype, B) Female paratype. Scale $=1$ $\mathrm{mm}$.

Variation. Male. Total length: 4.8-5.2 mm; humeral width: $2.5-3.0 \mathrm{~mm}$. Female (Fig. 1B). Total length: 4.8-5.3 mm; humeral width: 2.7-3.0. Similar characters to male, except that clypeus and protibia bear prominent teeth. Also, tibiae unmodified, protibia without pre-apical notch on inner margin (Fig. 2F) and internal margin of metatibia smooth (Fig. $2 \mathrm{H}$ ).

Etymology. The specific name alludes to the Quechua language word "Iskay Pachak" that means two hundred, because this species was described during the commemoration of bicentennial of Peruvian Republic (1821-2021).

Differential diagnosis. The two Cryptocanthon species previously recorded from Peru are clearly distinguishable from C. iskaypachak, because C. campbellorum has well-developed wings, vertical 
surface of clypeus foveate and pseudepipleuron with basal fovea and C. paradoxus has posterior pronotal angles strongly incised and pygidium with median depression at base. Also, parameres of C. campbellorum (Howden, 1973, Plate III, Fig. 22; Cook, 2002, Fig. 29) and C. paradoxus (Cook, 2002, Fig. 174) are distinct. According to its combination of morphological characters, C. iskaypachak is related to the species included in the so-called Andean species group (Cook, 2002), which have as synapomorphy a non-umbilicate type of head punctuation.

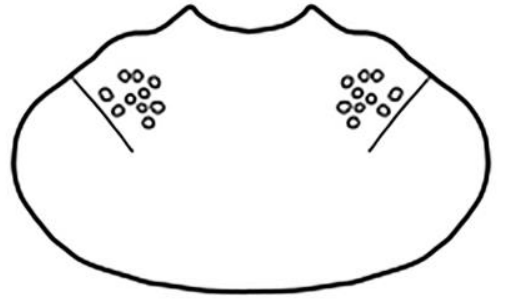

A

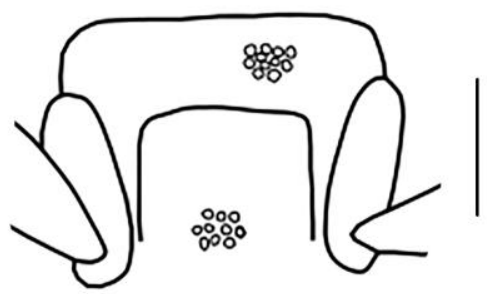

D
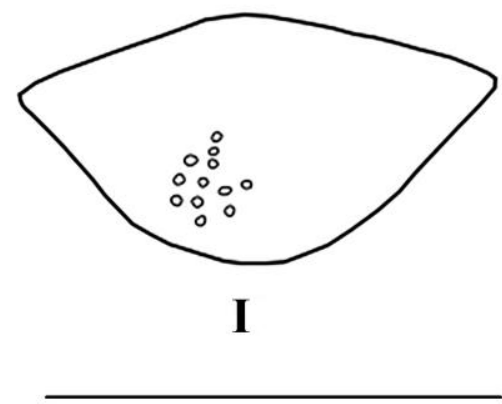

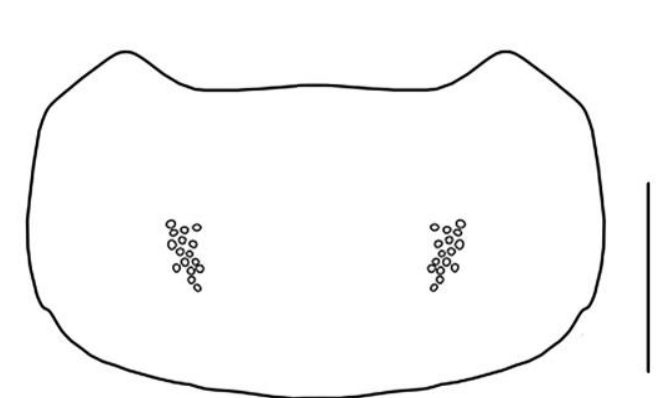

B

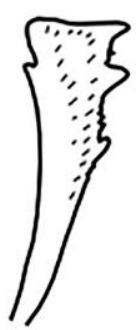

$\mathbf{E}$

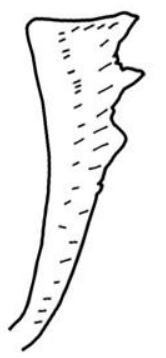

F

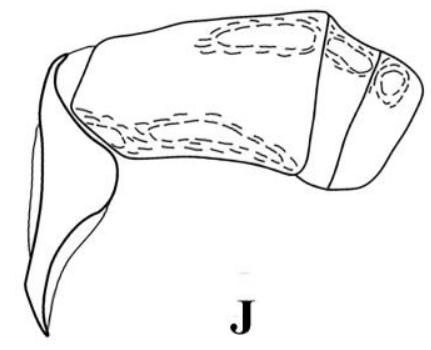

G
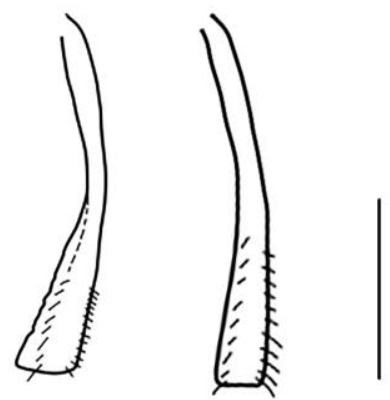

$\mathbf{H}$

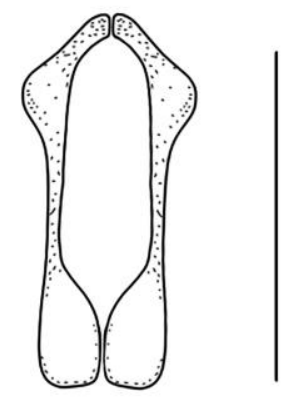

$\mathbf{K}$

Figure 2. Cryptocanthon iskaypachak sp. nov. body parts: A) head, B) pronotum, C) inflexed portion of elytron, D) meso-metasternum, E) male protibia, F) female protibia, G) male metatibia, H) female metatibia, I) pygidium, J) aedeagus lateral view, K) aedeagus caudal view. Scale $=1 \mathrm{~mm}$. 
The C. iskaypachak specimens are keyed to different species applying the available keys to South American Cryptocanthon species. Following the key proposed by Cook (2002), these are keyed to Cryptocanthon napoensis Cook, 2002, but this species has male protibia strongly notched near apex and pygidium with median depression at base. According to the key by Arias and Medina (2014), these are keyed to Cryptocanthon pulidoae Arias \& Medina, 2014, but this species has posterior pronotal angles obtusely curved, not incised and male metatibia has internal margin smooth. Applying the key by Martinez-Revelo et al. (2020), these are keyed to Cryptocanthon mailinae Martínez-Revelo, Torres \& Neita, 2020, but this species has pseudepipleuron with stria eight complete and pygidium with median depression at base. Also, parameres of $C$. napoensis (Cook, 2002, Fig. 164), C. pulidoae (Arias \& Medina, 2014, Fig. 5f) and C. mailinae (Martínez-Revelo et al., 2020, Fig. 11i) are distinct.

Although C. iskaypachak is clearly distinguishable from its relatives by the combination of characters presented, its endophallites have not been described. According to growing evidence, the endophallus characters of the Scarabaeinae are important for species delimitation (Zunino, 2012; Medina et al., 2013) and could provide crucial information for to resolve phylogenies (Tarasov \& Solodovnikov, 2011; Tarasov \& Génier, 2015). The revision performed by Cook (2002) is still the most comprehensive work about the genus Cryptocanthon; however, species description, species groups and cladistic analysis presented by this author were supported largely on external morphological characters. After the male genitalia of the Scarabaeinae was studied for a worldwide sample of tribes (Medina et al., 2013), the endophallites were incorporated as diagnostic elements in descriptions and determination of Colombian species of the genus Cryptocanthon (Arias \& Medina, 2014; Martínez-Revelo et al., 2020). Currently, internal sclerites of endophallus have been drawn for 14 Cryptocanthon species, that is, these are still unknown for around $67 \%$ of known species, which with the exception of Cryptocanthon peckorum Howden, 1973, are recorded outside of Colombia.

Distribution and habitat (Fig. 3). Known only from type locality. According to label data, vegetation is Puna grassland, at 3,500 $\mathrm{m}$ of altitude, and specimens were collected using unbaited pitfall traps. Due to the presence of cattle in the area, herbivore dung could be a potential food source for this species. Most Cryptocanthon species inhabit litter of lowland and montane wet forests (Cook, 2002), as has been widely documented for C. peckorum, a species collected in tropical forests of Brazil and Colombia using dung-baited traps (Andresen, 2003; Ratcliffe, 2013; Cajaiba et al., 2017; Noriega et al., 2021). However, some species have been recorded from Paramo province, high cordilleras above 3,000 m of altitude in Colombia (Cryptocanthon altus Howden, 1973, Cryptocanthon buriticaorum Arias \& Medina, 2014, Cryptocanthon escobari Cook, 2002) and Venezuela (Cryptocanthon andersoni Cook, 2002, Cryptocanthon punctatus Cook, 2002). As far as we known, it is the first Cryptocanthon recorded in these ecological conditions. As can be seen in the distribution map, C. iskaypachak is spatially segregated from C. campbellorum and C. paradoxus, species that inhabit lowland and montane wet forests in Peru, respectively. 


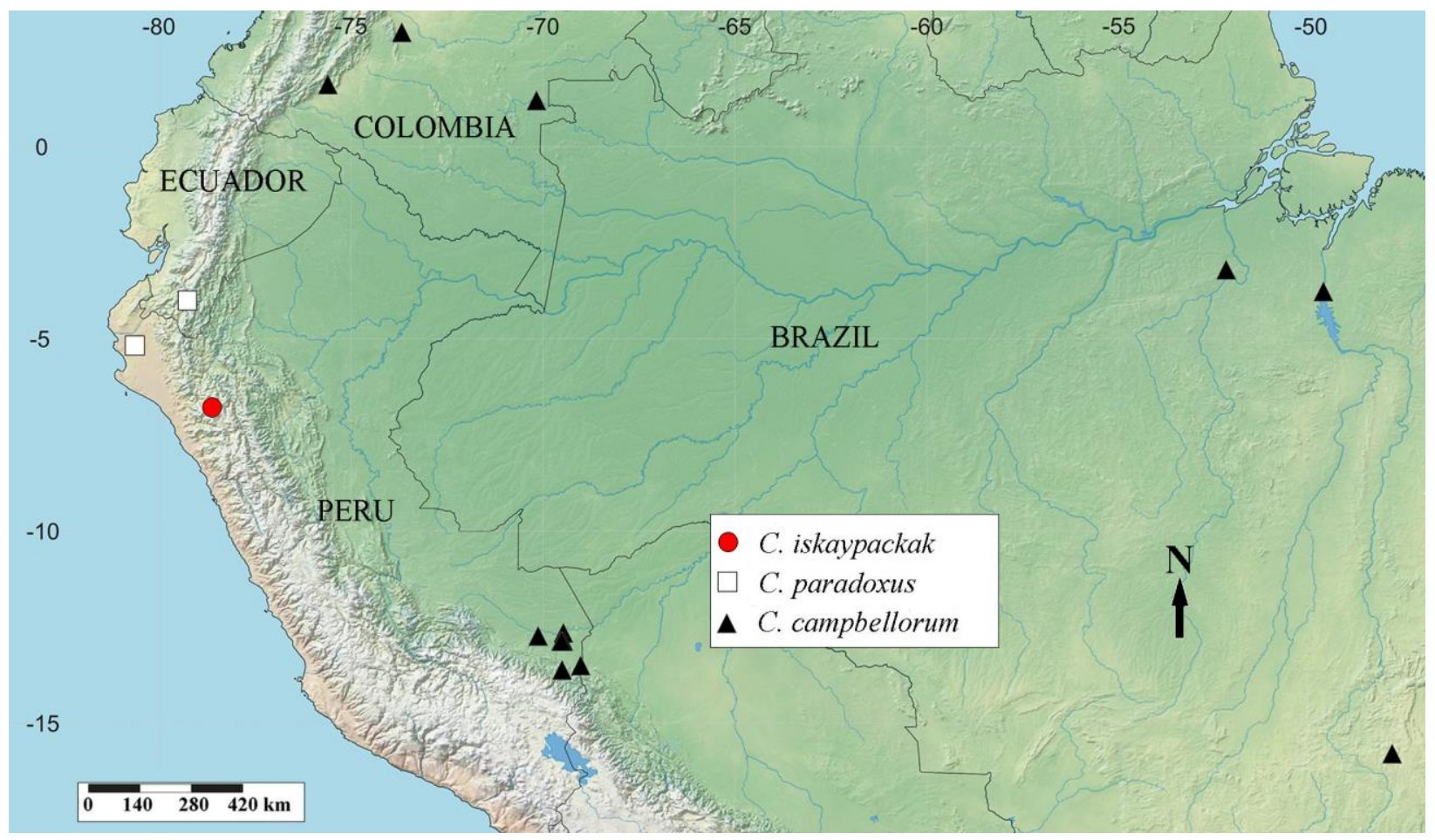

Figure 3. Distributional map of Cryptocanthon species recorded in Peru, including South American neighboring countries: C. iskaypachak (red circle), C. paradoxus (white squares) and C. campbellorum (black triangles).

ACKNOWLEDGMENTS. The author thanks to Clorinda Vergara for her constant support at MEKRB and Raquel Sánchez for kindly donation of specimens. Also, to two anonymous reviewers for their valuable suggestions that improved a previous version of the manuscript.

\section{LITERATURE CITED}

Andresen, E. (2003) Effect of forest fragmentation on dung beetle communities and functional consequences for plant regeneration. Ecography, 26, 87-97.

Arias, J. A., Medina, C. A. (2014) Three new species of Cryptocanthon Balthasar, 1942 (Coleoptera: Scarabaeidae: Scarabaeinae) from Colombia. Caldasia, 36 (1), 165-180. https://doi.org/10.15446/caldasia.v36n1.43898

Balthasar, V. (1942) Neue Scarabaeiden aus Süd-Amerika. 72. Beitrag zur Kenntnis der Scarabaeiden. (Col.). Casopis Ceskoslovenske Spolecnosti Entomologicke, 39, 36-44.

Cajaiba, R. L., Perico, E., Dalzochio, M. S., da Silva, W. B., Bastos, R., Cabral, J. A., Santos, M. (2017) Does the composition of Scarabaeidae (Coleoptera) communities reflect the extent of land use changes in the Brazilian Amazon? Ecological Indicators, 74, 285-294.

https://doi.org/10.1016/j.ecolind.2016.11.018

Chamorro, W., Marin-Armijos, D., Asenjo, A., Vaz-De-Mello, F. Z. (2019) Scarabaeinae dung beetles from Ecuador: a catalog, nomenclatural acts, and distribution records. ZooKeys, 826, 1-343.

https://doi.org/10.3897/zookeys.826.26488 
Cook, J. (2002) A revision of the Neotropical genus Cryptocanthon Balthasar (Coleoptera: Scarabaeidae: Scarabaeinae). Coleopterists Society Monograph, 1, 1-96. https://doi.org/10.1649/0010-065x(2002)56[3:arotng]2.0.co;2

Génier, F. (2019) Endophallites: a proposed neologism for naming the sclerotized elements of the insect endophallus (Arthropoda: Insecta). Annales de la Société entomologique de France, New Series, 55, 482-484. https://doi.org/10.1080/00379271.2019.1685907

Hadley, A. (2006) CombineZM public domain image processing software. Available at: https://combinezp.software.informer.com (accessed on 20 July 2021).

Howden, H. F. (1973) Revision of the New World genus Cryptocanthon Balthasar (Coleoptera: Scarabaeidae). Canadian Journal of Zoology, 51, 39-48. https://doi.org/10.1139/z73-007

Howden, H. F. (1976) New species in the genera Bdelyropsis, Cryptocanthon and Drepanocerus (Coleoptera: Scarabaeidae: Scarabaeinae). Proceedings of the Entomological Society of Washington, 78, 95-103.

Howden, H. F., Gill, B. D. (1987) New species and new records of Panamanian and Costa Rican Scarabaeinae (Coleoptera: Scarabaeidae). Coleopterists Bulletin, 41, 201-224.

Juárez-Noé, G., González-Coronado, U. (2021) Actualización a la lista de coleópteros (Insecta: Coleoptera) del bosque de neblina de Cuyas, Ayabaca-Región Piura, Perú. Graellsia, 77 (1), e126. https://doi.org/10.3989/graellsia.2021.v77.278

Martínez-Revelo, D. E., Torres, E., Neita-Moreno, J. C. (2020) El género Cryptocanthon (Coleoptera: Scarabaeidae) en Colombia: descripción de especies nuevas, distribución geográfica y conservación. Revista Mexicana de Biodiversidad, 91, e913156. https://doi.org/10.22201/ib.20078706e.2020.91.3156

Medina, C. A., Molano, F., Scholtz, C. (2013) Morphology and terminology of dung beetles (Coleoptera: Scarabaeidae: Scarabaeinae) male genitalia. Zootaxa, 3626 (4), 455-476. https://doi.org/10.11646/zootaxa.3626.4.3

Mora-Aguilar, E. F., Delgado, L. (2018) A new species of Cryptocanthon Balthasar (Coleoptera: Scarabaeidae: Scarabaeinae) from the Region of Chimalapas, Oaxaca, Mexico. The Coleopterists Bulletin, 72, 792-796. https://doi.org/10.1649/0010-065x-72.4.792

Noriega, J. A., Santos, A. M. C., Calatayud, J., Chozas, S., Hortal, J. (2021) Short- and long-term temporal changes in the assemblage structure of Amazonian dung beetles. Oecologia, 195, 719-736. https://doi.org/10.1007/s00442-020-04831-5

Ratcliffe, B. C. (2013) The dung- and carrion-feeding scarabs (Coleoptera: Scarabaeoidea) of an Amazonian Blackwater rainforest: results of a continuous, 56-week, baited-pitfall trap study. The Coleopterist Bulletin, 67 (4), 481-520.

https://doi.org/10.1649/0010-065X-67.4.481

Ratcliffe, B. C., Jameson, M. L., Figueroa, L., Cave, R. D., Paulsen, M. J., Cano, E., Beza-Beza, C., Jimenez-Ferbans, L., Reyes-Castillo, P. (2015) Beetles (Coleoptera) of Peru: A Survey of the Families. Scarabaeoidea. Journal of the Kansas Entomological Society, 88 (2), 186207. 
Shorthouse, D. P. (2010) SimpleMappr, an online tool to produce publication-quality point maps. Available at: http://www.simplemappr.net (accessed on 20 July 2021).

Tarasov, S., Génier, F. (2015) Innovative Bayesian and Parsimony phylogeny of dung beetles (Coleoptera, Scarabaeidae, Scarabaeinae) enhanced by ontology-based partitioning of morphological characters. PLoS ONE, 10 (3), e0116671. https://doi.org/10.1371/journal.pone.0116671

Tarasov, S., Solodovnikov, A. (2011) Phylogenetic analyses reveal reliable morphological markers to classify mega-diversity in Onthophagini dung beetles (Coleoptera: Scarabaeidae: Scarabaeinae). Cladistics, 27, 1-39. https://doi.org/10.1111/j.1096-0031.2011.00351.x

Vaz-de Mello, F. (2007) Revisión taxonómica y análisis filogenético de la tribu Ateuchini (Coleoptera: Scarabaeidae: Scarabaeinae). Tesis doctoral, Instituto de Ecología, A.C. Xalapa, Veracruz.

Vaz de Mello, F., Edmonds, W. D., Ocampo, F. C., Schoolmeesters, P. (2011) A multilingual key to the genera and subgenera of the subfamily Scarabaeinae of the New World (Coleoptera: Scarabaeidae). Zootaxa, 2854, 1-73. https://doi.org/10.11646/zootaxa.2854.1.1

Wheeler, Q. D., Platnick, N. I. (2000) The phylogenetic species concept (sensu Wheeler and Platnick). Pp. 55-69. In: Wheeler, Q. D., Meier, R. (Eds.). Species Concepts and Phylogenetic Theory: A Debate. Columbia University Press, New York, NY.

Zunino, M. (2012) Cuarenta años de anatomía de las piezas genitales en la taxonomía de los escarabajos Coleoptera: Scarabaeoidea): el estado del arte. Dugesiana, 18 (2), 197-206. https://doi.org/10.32870/dugesiana.v18i2.4027 